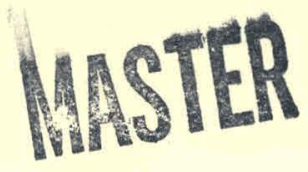

A Comparative Evaluation of Recent Reports on the Energy Conservation Potential from Cogeneration

\author{
R. W. Barnes \\ O. H. Klepper
}

OAK RIDGE NATIONAL LABORATORY OPERATED BY UNION CARBIDE CORPORATION · FOR THE DEPARTMENT OF ENERGY 


\section{DISCLAIMER}

This report was prepared as an account of work sponsored by an agency of the United States Government. Neither the United States Government nor any agency Thereof, nor any of their employees, makes any warranty, express or implied, or assumes any legal liability or responsibility for the accuracy, completeness, or usefulness of any information, apparatus, product, or process disclosed, or represents that its use would not infringe privately owned rights. Reference herein to any specific commercial product, process, or service by trade name, trademark, manufacturer, or otherwise does not necessarily constitute or imply its endorsement, recommendation, or favoring by the United States Government or any agency thereof. The views and opinions of authors expressed herein do not necessarily state or reflect those of the United States Government or any agency thereof. 


\section{DISCLAIMER}

Portions of this document may be illegible in electronic image products. Images are produced from the best available original document. 
Printed in the United States of America. Available from National Tecturical Infurmaliun Service

U.S. Department of Commerce

5285 Port Royal Road, Springfield, Virginia 22161

Price: Printed Copy $\$ 5.25$; Microfiche $\$ 3.00$

This report was prepared as an account of work sponsored by an agency of the United States Government. Neither the United States Government nor any agency thereof, nor any of their employees, contractors, subcontractors, or their employees, makes any warranty, express $\mathrm{or}$ implien, $\mathrm{nnr}$ assımes any legal liability or responsibility for any third party's use or the results of such use of any information, apparatus, product or process disclosed in this report, nor represents that its use by such third party would nnt-infringe privately nwned rights 
ORNL/TM-6602

Contract No. W-7405-eng-26

Engineering Technology Division

A COMPARATIVE EVALUATION OF RECENT REPORTS ON THE ENERGY CONSERVATION POTENTIAL FROM COGENERATION

R. W. Barnes, Principal Investigator

Dow Chemical U.S.A., Midland, Michigan

O. H. Klepper, Coordinator

Oak Ridge National Laboratory

Date Published: February 1979

Preparcd by the

OAK RIDGE NATIONAL LABORATORY

Oak Ridge, Tennessee 37830

operated by

UNION CARBIDE CORPORATION

for the

DEPARTMENT OF ENERGY
NOTICE

This report was prepared as an account of work Sponsored by the United States Govemment. Neither the Energy, nor any of their employees, nor any of the contractors, subcontractors or any warranty, express or implied, or assues, makes liability or responsibility for the a or asumes, any lega! or usefulness of any information apparatus, product or process disclosed, of represents that its use would not infringe privately owned rights. 
THIS PAGE

\section{WAS INTENTIONALLY LEFT BLANK}


Page

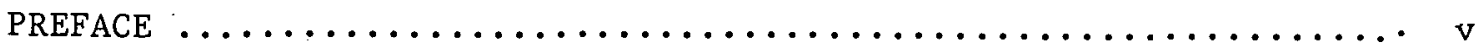

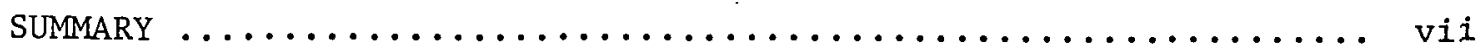

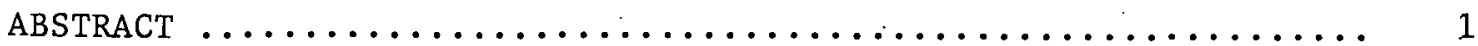

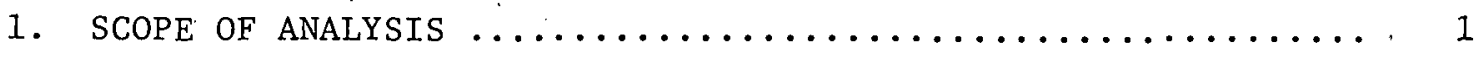

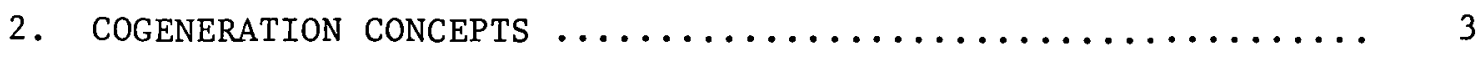

2.1 Technical Basis for Cogeneration ................... 3

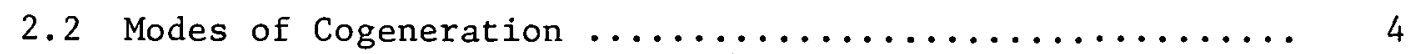

2.2.1 Steam turbine designs ................. 4

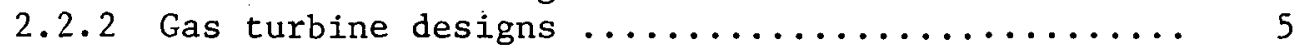

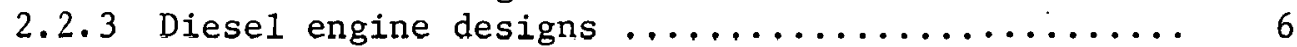

2.2 .4 Other modes of cogeneration .............. 7

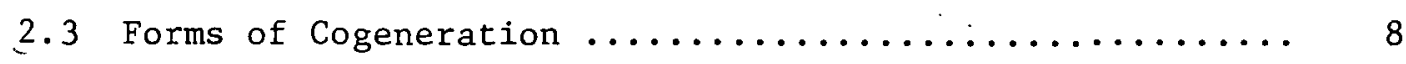

2.3.1 Industrial cogeneration systems $\ldots \ldots \ldots \ldots \ldots \ldots$

2.3.2 Central utility station cogeneration systems .... 12

2.3.3 Modular Integrated Utility Systems (MIUS) ...... 13

3. TECHNOLOGICAL COMPARISON OF COGENERATION STUDIES .......... 14

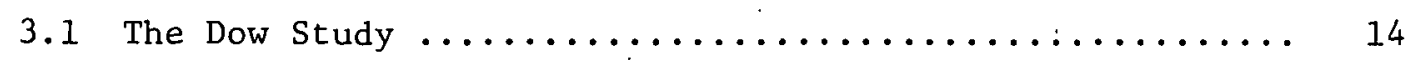

3.2 The Thermo Electron Studies .................... i7

3.3 The Resource Planning Associates (RPA) Study........ 20

3.4 The CONAES Industry Resource Group (IRG) Study ....... 23

3.5 The Ross and Williams (R\&W) Study .................... 24

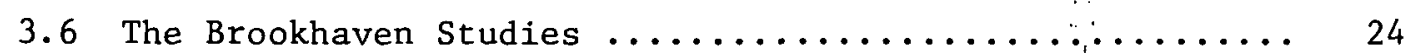

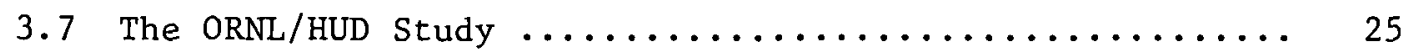

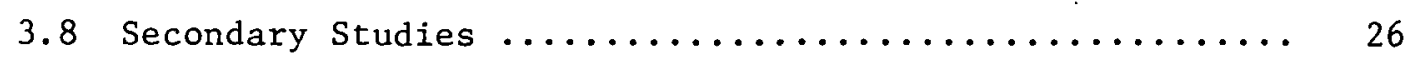

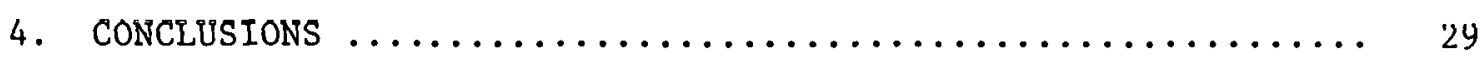

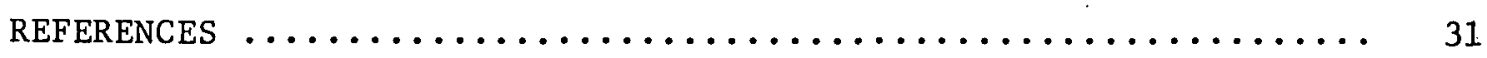

APPENDIX: ANALYSIS OF INDUSTRIAL POWER/STEAM RATIOS ........ 33 
THIS PAGE

\section{WAS INTENTIONALLY LEFT BLANK}




\section{PREFACE}

The practice of dual-purpose energy utilization, known as "cogeneration," has the potential to reduce substantially the total energy input required to accomplish certain kinds of energy-consuming tasks. The concept has received much publicity in the last few years. For example, increased cogeneration is now a specified component of the president's "National Energy Plan" recommended for supporting legislation by the Congress. Cogeneration can be implemented in several ways through a variety of mechanisms (modes). The potential for energy conservation depends upon the mode in which cogeneration is accomplished and the degree to which it is installed in each of its forms.

Because of the complex relationships involved in the variety of approaches to cogeneration, it has been difficult to identify the reasons for the rather wide differences observed in various published estimates of the energy conservation potential from cogeneration. The purpose of this report is to describe the primary modes and forms of cogeneration and to define the variables which influence the energy conservation potential from each type of implementation. Using the taxonomy thus developed, several published projections of cogeneration potential are analyzed and compared. 


\section{THIS PAGE}

\section{WAS INTENTIONALLY LEFT BLANK}


SUMMARY

Cogeneration as commonly known refers to the simultaneous production of a flow of electricity and a flow of useful heat from a single fuel input. In practice, there are several forms (types of systems) in which cogeneration can be implemented, and there are several modes (technology alternatives) which can be employed within each form. Each feasible combination of form and mode will produce electricity and heat in different proportions, will have different economics, and will be influenced differently by institutional and energy policy variables.

The magnitude of future energy savings from cogeneration will depend on the form and mode of implementation, the demand characteristics for the heat and electricity flows produced, and the extent to which potentially viable applications will be actually implemented. Affecting the degree of implementation will be not only economic considerations but also institutional issues such as exposure to government regulation and the availability of personnel with appropriate skills.

Several investigators have published estimates of the possible future contribution by cogeneration to energy conservation. Each investigator has assumed different values for the magnitude and effect of the various influencing parameters; consequently, we find a wide range of expected energy savings in the reported estimates.

Table 1 lists projections of future energy savings from cogeneration as reported in several different studies. It is important to distinguish between (1) the amount of savings estimated to be technologically feasible, (2) the savings estimated when economic limitations are considered, and (3) the estimated savings from actual implementation when all constraints (including institutional factors) are considered. Also, as shown in the table, energy attributable to industrial steam/power cogeneration should be distinguished from that attributable to district heating and Modular Integrated Utility Systems (MIUS). In general, the former two types of applications do not overlap, and the resulting estimated savings are additive With this consideration, when appropriate projections are combined, the total technological and economic potential for energy savings estimates ranges from 6 to 10 quads/year (by 1985). Fewer 
viii

estimates of expected actual implementation levels have been made, but these range from 0.5 to 4 quads of energy savings within 10 to 35 years. 


\title{
A COMPARATIVE. EVALUATION OF RECENT REPORTS ON THE ENERGY CONSERVATION POTENTIAL FROM COGENERATION
}

\author{
R. W. Barnes
}

\begin{abstract}
Most of the electricity generated in the U.S. and the heat used by industry, buildings, and homes are produced independently from the combustion of separate fuels. Cogeneration, the combined production of electricity and useful heat, could reduce significantly the total amount of fuel required. This report discusses areas of application and alternative technologies for cogeneration. Projections by various investigators indicate potential U.S. energy savings from $I$ or $2 \%$ up to almost $10 \%$. Several of the published estimates of potential energy conservation benefits from cogeneration are analyzed and reduced to common bases for comparison. Significant differences in the various projections arise from differences in estimating the size of the industrial steam demand and from divergent assumptions concerning the tractability of various implementation problems.
\end{abstract}

\section{SCOPE OF ANALYSIS}

The cogeneration studies (reports) that were reviewed in our work can be grouped into two categories: (1) those that developed new or previously unreported basic data, and (2) those that made projections based on such data.

Little basic study has been devoted to the potential for cogeneration in the United States. We have identified and reviewed nine reports covering the first type of study (see Table 1 ).$^{1-9}$ These basic studies will receive most of the attention in this report; however, a few category 2 reports ${ }^{10-12}$ will be discussed, primarily to show their relationship to the basic studies. 
Table 1. Estimates of future ene-gy conservation from cogeneration ${ }^{a} \mid 10^{15} \mathrm{Btu} /$ year (quads)]

\begin{tabular}{|c|c|c|c|c|c|c|c|c|c|}
\hline & \multicolumn{3}{|c|}{$\begin{array}{l}\text { Indefinite future - based on } \\
\text { present energy use }\end{array}$} & \multicolumn{3}{|c|}{1985} & \multicolumn{3}{|c|}{$2000 / 2010$} \\
\hline & $\begin{array}{l}\text { Technolugical } \\
\text { potential }\end{array}$ & $\begin{array}{l}\text { Technological } \\
\text { and economic } \\
\text { potential }\end{array}$ & $\begin{array}{c}\text { Planned } \\
\text { or } \\
\text { expected } \\
\text { (actual) }\end{array}$ & $\begin{array}{l}\text { Technological } \\
\text { potential }\end{array}$ & $\begin{array}{l}\text { Technological } \\
\text { and economic } \\
\text { potential }\end{array}$ & $\begin{array}{l}\text { Planned } \\
\text { or } \\
\text { expected } \\
\text { (actual) }\end{array}$ & $\begin{array}{l}\text { Technological } \\
\text { potential }\end{array}$ & $\begin{array}{l}\text { Technological } \\
\text { and economic } \\
\text { potential }\end{array}$ & $\begin{array}{c}\text { Planned } \\
\text { or } \\
\text { expected } \\
\text { (actual) }\end{array}$ \\
\hline \multicolumn{10}{|l|}{ Industrial cogeneration } \\
\hline $\begin{array}{l}\text { Dow study } \\
\text { Thermo Electron study } \mathrm{I}^{2} \\
\text { Thermo Electron study } \mathrm{II}^{3} \\
\text { Industry Resource Group } \\
\text { (CONAES study) } \\
\text { Ross \& Williams study } \\
\text { RPA study }{ }^{6}, c\end{array}$ & $1.2-4.6$ & & 2.6 & $1.7-6.9$ & $\begin{array}{c}1.5 \\
0.6-5.2\end{array}$ & $\begin{array}{l}1.5^{b} \\
0.5-0.7^{a}\end{array}$ & $6-10$ & & $2-4$ \\
\hline \multicolumn{10}{|l|}{ Jtility central station } \\
\hline $\begin{array}{l}\text { Brookhaven study } \mathrm{I}^{7} \\
\text { Brookhaven study } \text { II }^{8}\end{array}$ & & $\begin{array}{l}3.3-3.8 \\
4.7\end{array}$ & & & 5.2 & & & 5.0 & \\
\hline \multicolumn{10}{|l|}{$\frac{\text { Hodular Integrated Utility }}{\text { Systems (MIUS:) }}$} \\
\hline $\begin{array}{l}\text { Ross \& Williams } \\
\text { ORNL/HUD }\end{array}$ & & & 0.9 & & & & & $0.3-0.6^{e}$ & \\
\hline
\end{tabular}

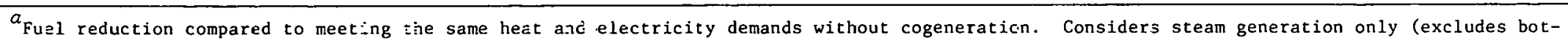
toming cycles for waste heat recovery and also toppirg cycles on direct process heat).

$b_{\text {With government action. }}$

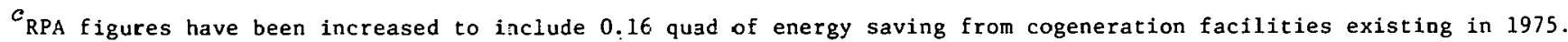

$d_{\text {Without government action. }}$

$e_{\text {Residential sector oniy. }}$ 


\section{COGENERATION CONCEPTS}

\subsection{Technical Basis for Cogeneration}

When energy in the form of heat is released by fuel combustion, it can perform useful work. In general, this work is accomplished by heating a working fluid such as steam or combustion gases and using the energy transported in the fluid to spin a turbine or move a piston. For a given amount of energy released, more work can be obtained from higher temperatures in the working fluid. Thus, it is desirable from the thermodynamic efficiency viewpoint to utilize energy from fuels at the maximum achievable combustion temperature. Unfortunately, there are two factors which constrain the achievement of this objective.

The first constraint is the physical capability of materials (engine components, etc.) to withstand elevated temperatures. Alleviation of this constraint is progressing through advances in metallurgy and through the design of energy transformation systems which can effectively utilize higher-temperature components. At present, we are generally restricted to the use of working fluid temperatures of below $1093^{\circ} \mathrm{C}\left(2000^{\circ} \mathrm{F}\right)$.

The second constraint arises from the nature of the task for which the energy is being used. Many industrial process heating applications and all residential and commercial space heating methods require temperatures of less than 149 to $260^{\circ} \mathrm{C}\left(300\right.$ to $\left.500^{\circ} \mathrm{F}\right)$. Utilizing a fuel capable of producing 1093 to $1649^{\circ} \mathrm{C}$ (2000 to $3000^{\circ} \mathrm{F}$ ) temperatures for these applications results in a loss of potential available work. Dual-purpose systems that can utilize the higher-temperature energy component of a working fluid to generate electricity and then exhaust the reduced-temperature fluid for other applications can significantly improve the overall efficiency of energy use. However, the potential improvement is governed by many factors ranging from the technological characteristics of various dual-purpose systems, to the availability of fuels, and to the demand characteristics of the energy flows involved.

The term cogeneration embraces a variety of dual-purpose systems which can produce both electricity and useful output heat flows. To aid in analysis of the various published projections of the potential 
for cogeneration, we will use a two-dimensional classification system. One dimension will be the "mode," referring to the technology employed; the other will be the "form," referring to the type of system or the user environment in which the cogeneration system is installed.

\subsection{Modes of Cogeneration}

There are several technologies which might be used in a cogeneration system; however, only three have practical significance at the present time. These are also the only ones considered in the projections analyzed in this report. The technologies are (1) steam boiler/steam turbine designs, (2) gas turbine designs, $*$ and (3) diesel engine designs.* The pertinent characteristics of each are reviewed below.

\subsubsection{Steam turbine designs}

Steam technology has been widely used for more than 100 years and is the basis for most of our present electrical power generation. It is also used extensively for industrial process heating and for space heating in buildings; consequently, steam-based systems are the most likely application areas for cogeneration. In a steam-based cogeneration system, steam is produced in a boiler at a temperature (and pressure) substantially higher than that required for the associated process or space heat requirement. The high-temperature steam is passed through a steam turbine which turns a generator to produce electricity, and the exhaust steam from the turbine is utilized for the heating applications.

Steam-turbine-based cogeneration produces the lowest ratio of electricity to heat output of the three modes. Approximately 10 to $15 \%$ of the fuel input is converted to electricity, while about 70 to $75 \%$ of the fuel energy will appear in the exhaust steam. These proportions are affected by the initial steam temperature and pressure and by the exhaust steam temperature and pressure. For relatively high initial steam pressure

* It should be noted that gas turbines can be operaled with clean liquid fuels and diesel engines can be operated with fuels other than diesel oil. 
and temperature [i.e., $11,030 \mathrm{kPa}(1600 \mathrm{psig})$ and $538^{\circ} \mathrm{C}\left(1000^{\circ} \mathrm{F}\right)$ ] and also a relatively high turbine exhaust pressure [i.e., $4140 \mathrm{kPa}(600$ psig)], about $8 \%$ of the fuel input will be converted to electricity and $77 \%$ will be in the exhaust steam. On the other hand, for the same initial steam conditions and for a. low exhaust steam pressure of $345 \mathrm{kPa}$ (50 psig), about $16 \%$ of the fuel goes into electricity and about $69 \%$ to the steam. If the output heat flow can be used in the form of hot water [at $104^{\circ} \mathrm{C}\left(220^{\circ} \mathrm{F}\right)$, for example] such as in district heating systems, as much as $30 \%$ of the fuel input can be converted to electricity with about 55\% going to the hot water flow.

A convenient parameter in comparing cogeneration systems is the ratio of electrical energy produced (at $3412 \mathrm{Btu} / \mathrm{kW} / \mathrm{hr}$ ) to output heat flow (in Btu's). This ratio has been termed the alpha value and, based on the data given above, can vary from 0.1 to 0.55 for the steam turbine mode, depending on whether the exhaust heat is used in the form of highpressure steam or hot water, respectively.

An important consideration in cogeneration systems is balancing the two forms of energy output. Since the steam turbine mode normally produces a lower ratio of electricity to heat than the other modes, the operating level of a given system will be controlled by the steam (or hot water) demand. Variable electricity loads are met by providing the capability to directly condense some portion of the exhaust steam from the turbines. By this means the alpha ratio can be increased; however, some efficiency in fuel utilization is sacrificed.

\subsubsection{Gas turbine designs}

In the gas turbine mode of cogeneration, fuel gas (or a clean distillate oil) is burned in a combustion chamber and the hot combustion gases expand through a turbine coupled to a generator to produce electricity. In nonrecuperated* versions, the exhaust gases exit at high temperatures [above $482^{\circ} \mathrm{C}\left(900^{\circ} \mathrm{F}\right)$ ] and can be used directly for heat or

\footnotetext{
*A heat exchanger (recuperator) can be installed on gas turbines to warm the combustion air with heat from the exhaust, thereby improving the overall thermal efficiency.
} 
passed through a waste heat boiler to produce steam for process use or space heating. In some systems, the steam may be utilized for additional electricity generation, creating what is known as a combined cycle operation. Another variant of this mode is the closed-cycle turbine, wherein pressurized air is heated (within a heat exchanger) in a separate combustion chamber and the hot air is used as the working fluid in the gas turbine. Some energy-use efficiency is sacrificed in this cycle; however, a wider variety of fuels can be used.

For the same process steam (or useful heat) conditions, the gas turbine mode of cogeneration usually generates more power per unit of steam flow than the steam turbine mode. Either open- or closed-cycle gas turbines may have alpha values of up to 0.75 , with the fuel economy being inversely proportional to the alpha value. For example, the fuel chargeable to power* from gas turbine cogeneration can range from 3200 to 7000 $\mathrm{Btu} / \mathrm{kWhr}$, as compared with $4600 \mathrm{Btu} / \mathrm{kWhr}$ for a back-pressure steam turbine mode. It also should be recognized that an open-cycle gas turbine has a sizable advantage in combustor efficiency over a steam boiler furnace. Indirectly heated gas turbine cycles, however, are taxed with about the same furnace efficiency as a steam system and will never show a fuel economy advantage in direct comparison to a steam cogeneration system.

\section{2 .3 Diesel engine designs}

Diesel engines have been available for more than 50 years, and a mature technology producing a widely used and reliable product has evolved. Diesel-powered electricity generation is trequently used in smaller, remote installations not economically serviced by the large central generating stations. Diesel-powered generators have also been used for emergency power or to meet peak demand loads in the larger systems.

* The fuel chargeable to power concept assumes that steam (or useful heat) is the primary desired output and could be produced without cogenerated electricity from a given amount of fuel. When electricity is cogenerated, additional fuel must be supplied above that required for the steam alone, and this additional fuel is charged against the electricity. 
Diesel engines primarily use liquid fuels; they will, however, perform well using the heavier and less expensive grades. Fuel consumption for electric power generation is somewhat higher than for the other modes. In a diesel-driven cogeneration system, the fuel chargeable to power will amount to about 6000 to 7000 Btu/kWhr, depending on the extent of waste heat utilization. Although the heat content of the hot exhaust gases can be converted to usable steam, about $30 \%$ of the engine heat output is rejected in the engine cooling fluids at temperatures of $121^{\circ} \mathrm{C}\left(250^{\circ} \mathrm{F}\right)$ or lower. In most industrial applications, heat flows at these low temperatures have no utility; however, such low-quality heat would be suitable for space heating applications.

The diesel engine mode of cogeneration produces a higher proportion of electricity than either of the other modes. If steam is produced only from the exhaust gases, alpha values of up to 1.5 may be obtained. If the heat content of the cooling fluids is utilized, alpha values are still above 1.0 .

\section{2 .4 Other modes of cogeneration}

At least two studies ${ }^{2}, 6$ have indicated some potential for cogenerating electricity by the topping of direct process heat. In practice, this would entail the generation of electricity with a gas turbine or a diesel engine and the use of the exhaust gases to heat a process reactor, kiln, or other such industrial equipment. There is no significant use of this technique in industry today. The studies mentioned indicated an economic potential equivalent to 10 to $50 \%$ of the steam topping potential. However, because of the lack of experience with such systems, both studies caution against use of their estimates, so they are not included in this report.

Work has been proceeding in recent years on the development of lowtemperature Rankine cycle turbines for conversion of waste heat to electricity. Although this would also represent a mode of cogeneration, the technique is still under development and the economics are largely unknown. Some estimates ${ }^{2}, 6$ of the potential have been attempted, but they show only a fraction (5-15\%) of the steam topping potential, so they have not been included in our analysis. 
At least two quite new technologies, fuel cells and solar cells with concentrating collectors, have been suggested for cogeneration systems. In both cases, electricity is produced together with a waste heat stream. Although these technologies might have future cogeneration potential, no studies of such potential have been reported, and consequently they have not been included.

\subsection{Forms of Cogeneration}

The three basic forms of cogeneration or types of implementation are (1) the industrial cogeneration system, (2) the central utility station cogeneration system, and (3) the smaller MIUS, or total energy system. In the first form, steam will be the nominal principal product and electricity can be considered a by-product. In the second form, electricity is the primary product and the heat flow is a by-product. In the MIUS systems, neither energy flow dominates. Not all modes of cogeneration are feasible within each form; feasibility relationships are shown in Table 2 .

\subsubsection{Industrial cogeneration systems}

The attraction of industrial cogeneration systems results from the facts that U.S. industry produces large quantities of steam for use in various processes and that most of this steam is produced solely for process heat with no associated electrical power generation. It has been estimated $^{6}$ that in $1976, \sim 600 \times 10^{12}$ Btu of process steam was generated in industrial cogeneration systems (primarily steam turbine mode). This is less than $10 \%$ of the total industrial steam production. At a nominal alpha value of 0.2 , this represents $35 \times 10^{9} \mathrm{kWhr}$ of cogenerated electricity, which is about $4 \%$ of industrial electricity use. Thus, from either a total steam or total electricity requirement, it would appear that a several-fold increase in industrial cogeneration is technologically feasible. However, industry uses steam and electricity in widely varying proportions from one plant to another, and there is no assurance that any given industrial plant with the steam capability for additional cogeneration will also have an economic use for the electricity produced. 
Tajle 2. Feasibility of cogeneration alternatives

\begin{tabular}{|c|c|c|c|c|c|c|}
\hline \multirow{3}{*}{ Form of cogeneration } & \multicolumn{4}{|c|}{ Current technology } & \multicolumn{2}{|c|}{$\begin{array}{c}\text { Future } \\
\text { technology }\end{array}$} \\
\hline & \multicolumn{3}{|c|}{ Basic cycles } & \multirow{2}{*}{$\begin{array}{l}\text { Combined } \\
\text { cycle }\end{array}$} & \multirow{2}{*}{$\begin{array}{l}\text { Fuel } \\
\text { cell }\end{array}$} & \multirow{2}{*}{$\begin{array}{l}\text { Solar } \\
\text { cells }\end{array}$} \\
\hline & $\begin{array}{l}\text { Steam } \\
\text { turbine }\end{array}$ & $\begin{array}{l}\text { Combustion } \\
\text { turbine }\end{array}$ & $\begin{array}{l}\text { Diesel } \\
\text { engine }\end{array}$ & & & \\
\hline
\end{tabular}

Industrial plant producing byproduct electricity

Internal use only

External sale

$a$

b

$a$

$b$

$a$

$\dot{b}$

$a$

Electrical utility selling byproduct heat

Industrial sales only

Residential/commercial sale

Modular Integrated Utility Systems

(no external sales)

\footnotetext{
${ }^{x}$ Appears feasible.

$b_{\text {May have limited feasibility. }}$

${ }^{c}$ Appears infeasible.
} 
An analysis of a diverse group of 282 large industrial plants (Appendix A) indicates that about $35 \%$ of these plants have an electrical energy requirement equivalent to less than $10 \%$ of their steam energy use. Further, $80 \%$ of the plants in the group have an electrical energy demand requirement equivalent to less than $25 \%$ of their steam energy use. If this sample is representative of the totality of industrial energy use, we can conclude that industrial cogeneration by any mode having alpha values higher than 0.1 to 0.2 will entail substantial export (from the cogenerating plants) of the electricity produced. This means that realization of the full potential for cogeneration from the industrial steam base will require a cooperative effort between private industry and the electrical utilities to distribute and utilize the excess electricity effectively.

Regardless of the mode employed for industrial cogeneration systems, the potential for electricity production and for energy conservation is ultimately dependent upon the industrial requirement for process steam.* Although data on total industrial energy use are regularly collected and compiled by sector and by type of fuel, relatively little survey information is available to establish the energy allocated to steam generation.

Since industrial steam use is an important variable in estimating the potential for industrial cogeneration, we have analyzed the various bases for projecting future total industrial steam requirements. The results, shown in Table 3, indicate that the fuel input for industrial steam generation represents about $10 \%$ of total U.S. energy use and was $\sim 7$ quads in $19 / 3$. Based on historical industrial energy use, the fuel growth ratc of 3.5 to $4.0 \%$ /year fuel for steam will increase to about 10 quads in 1985. This is substantially lower than the 18.5 quads that would be projected from the steam-use data given in the pioneering analytical study ${ }^{13}$ at Stanford Research Institute (SRI). This work, published in 1972, has been widely used as a reference base in subsequent energy studies and also for some cogeneration projections. We have been unable to reconcile the

"Although electricity could be produced from topping systems installed on direct-fired process heating systems, such applications are rare or nonexistent at present and are not anticipated to increase during the foreseeable future. 
Table 3. Estimations and projections of industrial steam use ${ }^{a}$ (quads)

\begin{tabular}{|c|c|c|c|c|c|c|c|}
\hline \multirow[t]{2}{*}{ Source of data or projection } & \multicolumn{4}{|c|}{$\begin{array}{c}\text { Estimated level of fuel input } \\
\text { for industrial steam use } \\
\text { in base year }\end{array}$} & \multirow[t]{2}{*}{$\begin{array}{l}\text { Growth assumed } \\
\text { for projection }\end{array}$} & \multicolumn{2}{|c|}{$\begin{array}{l}\text { Projected level } \\
\text { of fuel input } \\
\text { for industrial } \\
\text { steam }\end{array}$} \\
\hline & 1968 & 1972 & 1973 & 1975 & & 1980 & 1985 \\
\hline Stanford Research Inst. ${ }^{13}$ & 10.13 & & & & $3.6 \% /$ year & & {$[18.5]$} \\
\hline Dow Chemical Company ${ }^{2}$ & 10.13 & & & & $\begin{array}{l}3.5 \% / \text { year to } 1980 \\
4.5 \% \text { thereafter }\end{array}$ & 16.5 & {$[21]$} \\
\hline Babcock \& Wilcox ${ }^{14}$ & & & 6.7 & & No projections made & & \\
\hline Dow Chemical Company ${ }^{15}$ & & 7.8 & & & No projections made & & \\
\hline $\begin{array}{l}\text { Thermo Electron Corp. }{ }^{2} \& \text { Amer. } \\
\text { Boiler Mfr. Assn. (ABMA) }\end{array}$ & & & & {$[6.7]^{b}$} & $\begin{array}{l}50 \% \text { in } 10 \text { years } \\
(4.1 \% / \text { year })\end{array}$ & & {$[10]$} \\
\hline
\end{tabular}

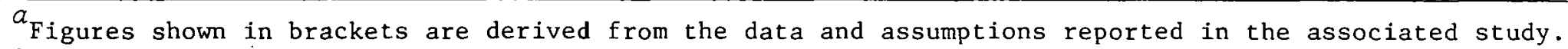

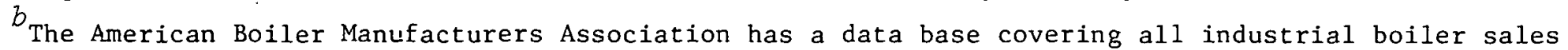
since before 1963. Tabulations of this data showing boiler purchases by individual industries provided a basis for estimating the total industrial steam capacity and also the distribution of this capacity to specific industries.

${ }^{c}$ Thermo Electron ${ }^{2}$ data for three industries (chemical, petroleum refining, and paper) show a total energy inptt to steam of 3.8 quads. ABMA data indicate that the three industries have installed $57 \%$ of total industrial boiler capacity additions in recent years. On this basis, total industrial steam fuel use would te $3.8 / 0.57=6.7$ quads. This number is probably slightly low, since the three industries analyzed have each grown faster than the average industrial growth in recent years and their boiler purchases in these years were probably a larger fraction of annual boiler sales (in steam capacity) than of total installed incustrial steam capacity. 
high level of industrial steam production ( $16.7 \%$ of national energy use) estimated by SRI with recent data developed in other independent studies (see Table 3).14,15 Consequently, we believe that 10 quads is a realistic expectation for 1985. However, an intensive energy conservation effort could reduce this even further.

\subsubsection{Central utility station cogeneration systems}

More than $90 \%$ of the conventional utility electricity produced in the U.S. is generated with steam-turbine-driven generators. The exhaust steam from these turbines represents in total about 10 quads/year of heat energy that is largely discarded. In theory, much of this discarded heat could be used for industrial process heating or for space heating of buildings.

Industrial utilization of exhaust steam from an electrical utility plant requires the plants concerned to be located in proximity (maximum 5-10 miles) to one another. The difference in criteria for optimal site locations for electrical power plants and private industrial plants represents a significant constraint to this form of cogeneration. Additional constraints arise from the need to match peak demand requirements for the electricity and steam flows and the fact that the industrial user must have a relatively large steam demand to make the project economical1y viable for the utility.

District heating systems represent another potential use of reject heat from central utility stations. In Sweden, $\sim 20 \%$ of the residential and commercial space and water heating requirements are met with hot water produced in central utility stations and circulated to the buildings involved. Steam-based district heating systems exist in many U.S. cities; however, their use has been declining, and in many cases the steam is supplied from a single-purpose boiler rather than from cogeneration. Hot water systems for district heating have technological advantages over steam (e.g., feasibility for longer transmission distances) and also permit higher efficiencies in the associated cogeneration operations. 


\subsubsection{Modular Integrated Utility Systems (MIUS)}

The MIUS concept is alternatively termed the total energy concept. In this form of cogeneration, the total energy requirements (heating, cooling, and electricity) of an activity such as a residential complex, a shopping center, or a community are supplied from a single integrated system. At present, the diesel engine (or a similar gas-fired engine) is the preferred mode for these systems. In general, MIUS installations are most successful when they are incorporated into an activity with reasonably level energy requirements and with a designed balance between heating, cooling, and electricity demand that is optimal with respect to the alpha value of the cogeneration system. In activities and locations with wide variations in energy demand over time, facilities required to meet peak demand loads may be idle much of the time, and MIUS installations may be uneconomic. 


\section{TECHNOLOGICAL COMPARISON OF COGENERATION STUDIES}

In this section of our analysis, each of the several cogeneration projections are characterized as to the mode and form of cogeneration postulated in the study and also as to their estimates of the level* of future use of heat and electricity from cogeneration. Although these characteristics are summarized in Table 4, there are many differences in the basic assumptions of each study, necessitating the discussion which follows.

\subsection{The Dow Study ${ }^{1}$}

I'his study evaluates only the potential for cogeneration to satisfy the industrial process steam requirement; the only mode of cogeneration examined is the steam turbine topping mode. Projections are made for two forms of cogeneration - individual industrial plant installations and central utility station installations. In addition, a projection is made for a feasible combination of these two forms.

One disadvantage of this study is that projections for the 1985 industrial steam requirement are based on the SRI study ${ }^{13}$ of 1972 using that estimate for 1968 industrial steam use, increased by 3.5\%/year until 1980 and by $4.5 \%$ year thereafter until 1985. As discussed previously, the SRII estimate of industrial steam use in 1968 appears to be higher than the actual figure. Since the Dow study projections from the SRI estimate use steam demand growth rates that make no allowance for a stimulated energy conservation effort or for the 1274-75 industrial slowdown, the Dow-projected 1985 total industrial steam demand appears to be substantially larger than that which will actually occur.

Based on economic relationships prevailing in 1975 and assuming an average construction cost escalation of $7.7 \%$ /year until 1985 , the Dow study estimates that steam turbine cogeneration in industrial plants will

\footnotetext{
* Because of the differences in their respeclive bases, many of the entries in Table 4 are derived using the data and assumptions of the associated study.
} 
Table 4. Technological comparison of cogeneration projections ${ }^{a}$

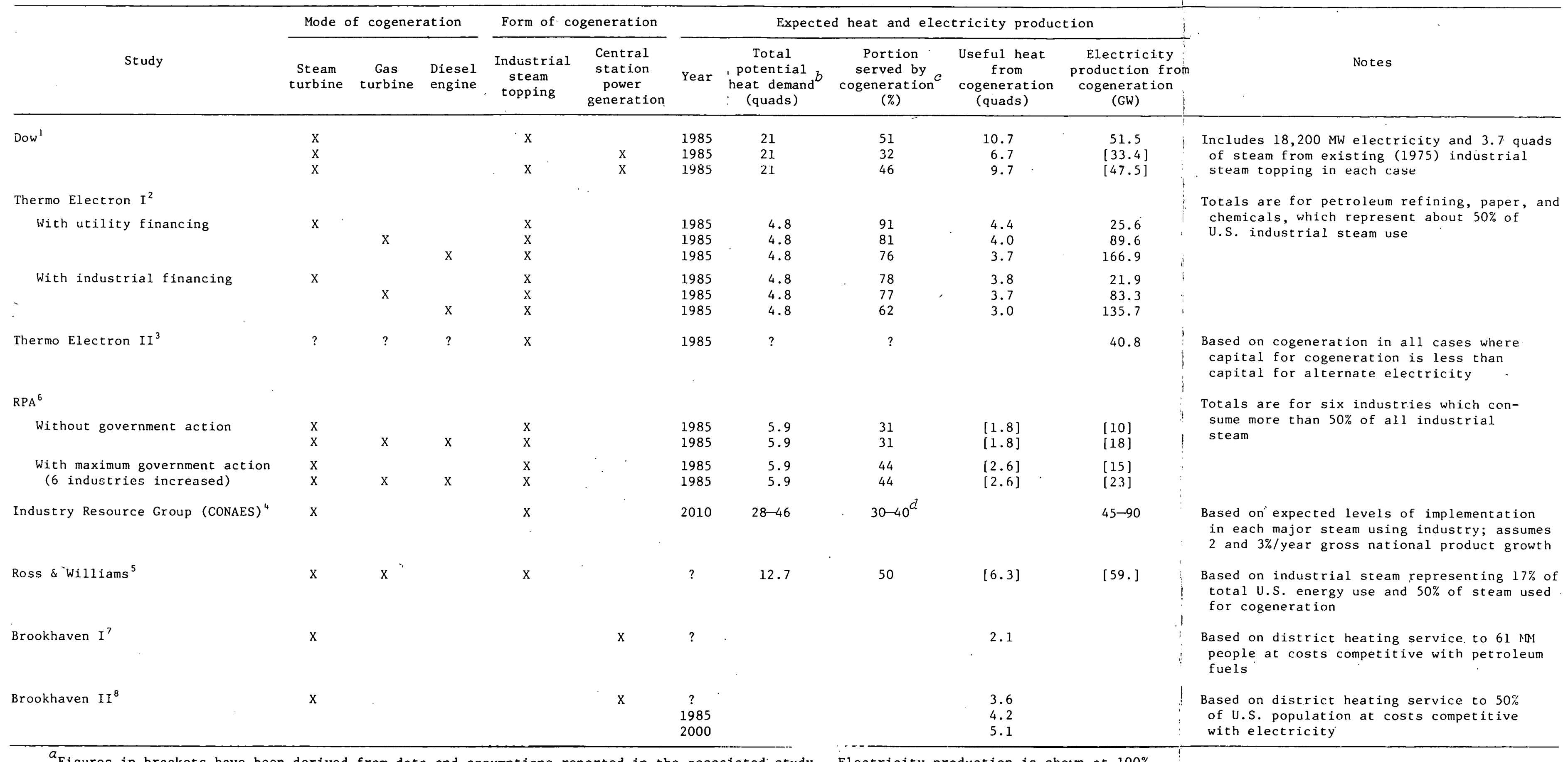

$a_{\text {Figures in brackets have been derived from data and assumptions reported in the associated study. Electricity production is shown at } 100 \%}$
capacity factor.

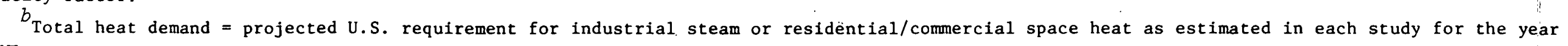
shown.

${ }^{c}$ Represents the percent that is technologically and economically feasible, unless indicated otherwise - as below.

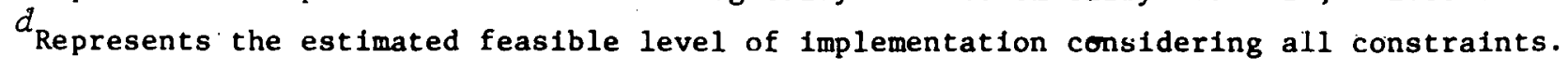


be economically feasible for installations producing 400,000 or more pounds of steam per hour. According to the Dow analysis of industrial steam generation practice, this represents $43 \%$ of total U.S. industrial steam production. However, some plants producing less than 400,000 1b/hr and currently cogenerating are expected to continue to do so, and the overal1 level of technical and economic feasibility for industrial cogeneration will equal $51 \%$ of the total industrial steam demand. This results in an estimate of 10.7 quads of industrial steam, 51,500 MW of electricity generation, and 1.5 quads of energy concervation in 1985 from industrial cogeneration.

For central utility station cogeneration, it is estimated in the Dow study (bascd on discussion with utility cumpduy representatives) that $1,000,0001 \mathrm{~b} / \mathrm{hr}$ of industrial. steam demand is the minimum economic level for cogeneration. On this basis, Dow researchers estimate that only $23 \%$ of the industrial steam is applicable. However, if existing Industrial in-plant cogeneration continues, the combined level of implementation by 1985 would equal $35 \%$ of the industrial steam demand, or 6.7 quads/year.

It is assumed in the Dow study that rngenerating central utility stations would each produce $2,000,000 \mathrm{lb} / \mathrm{hr}$ of by-product industrial sLedill on the average, and a steam capacity above this level would be used to produce elertririty with condensing turbines. On thio basis, the study does not develop a figure for central station electricity production from cogeneration only. However, since the Dow study does consiztenlly usc lie railo of $1.0 \mathrm{kWhr}$ of elétricity per $20.4 \mathrm{lb}$ of cogenerated steam, we have used this same relationship to obtain the electrical power generation level shown in Table 4 (33,400 MW). Energy saving in 1985 would be 1.1 quads from this form of cogeneration.

Similar $\perp$, a selieme of cumblned Industrial plant and central stations cogeneration that in total would satisfy $46 \%$ of the industrial steam demand is suggested in the Dow study. This approach would produce 9.7 quads of steam and 47,500 $\mathrm{MW}$ of electricity (from cogcncration), with an annual saving of 1.5 quads of energy.

Although major attention is given to the institutional (i.e., legalregulatory, attitudinal, and other intangible) problems in the Dow study, 
no attempt has been made to estimate the extent to which these problems will inhibit cogeneration. The study also fails to evaluate the extent to which dynamic load fluctuation patterns within an industrial plant might produce an imbalance between steam and electricity demands, thereby reducing the potential for dual-purpose steam-electricity generation.

\subsection{The Thermo Electron Studies ${ }^{2}, 3$}

The primary Thermo Electron study (TE-I) ${ }^{2}$ contains an in-depth analysis of heat use and flows by temperature levels in the chemical, petroleum refining, and paper and pulp industries. The TE-I study presents no data on the relationship of energy use in these three industries to the totality of U.S. industrial energy use. It is known, however, that these industries produce and consume a substantial portion of total industrial steam. Based on data from the American Boiler Manufacturers Association, we estimate that about $50 \%$ of industrial boiler capacity (and therefore $50 \%$ of steam production) is installed in the three industries.*

Using the data detail obtained from the Thermo Electron analysis, the maximum technological potential ${ }^{\dagger}$ for by-product electricity generation is calculated for each of the three industries. This maximum potential represents electricity from both "topping" (cogeneration) and "bottoming" cycles (waste heat recovery). The study then examines the economics of by-product electricity generation under three different sets of financial incentives. Projections of expected 1985 levels of implementation are made for each of the three industries under each alternative incentive plan. The projections do not reflect consideration of institutional constraints or include the effect of industrial operational requirements (i.e., dynamic load balancing) on expected levels of electricity production from cogeneration.

\footnotetext{
See footnote $b$, Table 3 .

† In the TE-I study, all industrial steam is considered to have potential for cogeneration, and the technological maximum by-product electricity is determined only by the temperature and pressure required in the process steam output.
} 
The TE-I report is concerned only with industrial by-product electricity and makes no separate evaluations or projections for central utility station cogeneration. However, in developing the economics of industrial cogeneration units, two financing alternatives are considered conventional industrial investment and utility ownership (or financing) of the cogeneration facility. Since utility ownership reduces financing costs and therefore the level of investment required, higher levels of cogeneration are found to meet the economic criteria for acceptability. Although the report shows projections of cogeneration output for both utility and industrial ownership, there is no discussion of the nnneronomic factors or conditions which might favor one over the other.

In developing the maximum technological potential for cogeneration, the 'LE-I rcport evaluates both the topping of industrial process steam and the topping of process heat within direct-fired operations. The report recognizes, however, that the latter activity has never had significant actual realization, and the potential electririty from cuch activity is not included in the final projections.

In the projections of industrial electricity generation, the Thermo Electron study included the contribution from bottoming of waste heat in each of the three industries. Since the energy potential from waste heat recovery is relatively small (less than $10 \%$ of the process steam energy) and is subject. to substantial uncertainlies, we have removed this conponent from the TE-I projections and show only the contribution from industrial steam topping in our tabulations.

Three modes of cogeneration are evaluated in the TF-T report: stcam turbine topping power, gas turbine topping power, and diesel engine topping power. For each mode, the relationship between electricity production and output steam characteristics has been determined and then applied to the steam use charactexistics developed from the heat utilizatiun analysis of the three industries in the study. From this step, the present (1975) maximum technological potential for cogeneration from each mode is obtained.

Having developed the maximum technological potential for cogeneration from each mode for each of the three industries, a projection to 1985 is made by first assuming an overall 50\% (4.1\%/year) growth for steam use in each industry between 1975 and 1985. Then, various economic criteria, as 
mentioned above, are applied to determine the expected levels of investment in cogeneration facilities. Since the economics of cogeneration facilities are more favorable for new plants than for the retrofitting of old plants, it was assumed that the expected $50 \%$ growth represented new plant construction entirely and, in addition, that $25 \%$ of the existing plants would be replaced with new capacity because of age and obsolescence.

Table 4 shows the TE-I projections for each mode of cogeneration and for the two types of financing (utility and industrial). The values shown for heat production and electricity generation are the maximum values, based on the most favorable economic incentive.

In general, as shown in Table 4, the TE-I study indicates that it would be economically attractive to cogenerate 62 to $91 \%$ of the 1985 industrial steam requirements. At this level, the equivalent electricity production is 22,000 to $167,000 \mathrm{MW}$, depending on the mode of cogeneration employed. Fuel savings, as shown in Table 1, would range from 0.6 to 5.2 quads/year, again depending on the mode of cogeneration.

Since the TE-I study shows a higher level of economic attractiveness for cogeneration than the Dow study, differences in economic assumptions between the two were reviewed. It was observed that the Thermo Electron study develops more attractive economics for cogeneration because of the effects of assumed financial incentives such as a 25 to $50 \%$ investment credit against taxes or $50 \%$ government financing for cogeneration facilities. These incentives increase the expected return on investment and therefore induce a higher level of cogeneration investment.

The differences between the Thermo Electron and the Dow studies, such as scope of industrial coverage and size of the estimated industrial steam base, preclude a meaningful comparison of the actual magnitude of future cogeneration outputs projected in each study. However, we can compare the effect of the financial incentives incorporated in the TE-I study with the Dow analysis by showing the fraction of maximum technological potential for cogeneration projected for each economic alternative. As shown in Table 5, both studies project a level of implementation of about half their respective estimates of the maximum technological potential. For the various additional economic incentives, the Thermo 
Table 5. Projected level of cogeneration based on alternative economic incentives ${ }^{a}$

\begin{tabular}{|c|c|c|c|c|c|c|}
\hline & \multicolumn{6}{|c|}{ Percent of maximum technological potential } \\
\hline & \multicolumn{3}{|c|}{ Industrial financing } & \multicolumn{3}{|c|}{ Utility financing } \\
\hline & $\begin{array}{l}\text { Base } \\
\text { case }\end{array}$ & $\begin{array}{l}\text { With } 50 \% \\
\text { investment } \\
\text { credit }\end{array}$ & $\begin{array}{l}\text { With } 50 \% \\
\text { government } \\
\text { financing }\end{array}$ & $\begin{array}{l}\text { Base } \\
\text { case }\end{array}$ & $\begin{array}{l}\text { With } 25 \% \\
\text { investment } \\
\text { credit }\end{array}$ & $\begin{array}{l}\text { With } 50 \% \\
\text { government } \\
\text { financing }\end{array}$ \\
\hline Dow study & 51 & & & & & \\
\hline TE-I study & 47 & 78 & 70 & 78 & 86 & 91 \\
\hline
\end{tabular}

Electron study shows the expected level of implementation increasing up to a high of $91 \%$ of the maximum potential.

A more recent report (TE-II), ${ }^{3}$ by the Thermo Electron Corporation presents an estimate of the feasible level of industrial cogeneration activity in 1985. Although no basis for the estimate is identified, the projections are quite likely derived from the previous work discussed above. The TE-II report estimates a fuel saving of 1.5 quads (Table 1) and a by-product electricity generation of 42,800 $\mathrm{MW}$. These values are near the lower end of the ranges presented in the TE-I study and appear to represent the estimated potential for the steam turbine topping mode. Although the projected level of fuel saving is somewhat high (about 20\%) with respect to the estimated level of by-product electricity generation, the projections are compatible with the Dow and the TE-I studies.

\subsection{The Resource Planning Associates (RPA) Study}

This study, which is the newest of those analyzed, represents the most comprehensive investigation performed to date on the potential for industrial cogeneration. The RPA study parallels the TE-I study in that industrial steam topping potential was the major consideration, and the three primary modes of cogeneration (steam turbine, gas turbine, and diesel engine) were evaluated. In addition to the chemical, paper, and petroleum refining industries discussed in the TE-I study, the RPA work 
also covered the steel, food, and textile industries. Both studies analyzed the effect of various possible government incentive programs on the attractiveness of cogeneration investments. The RPA study did not, however, consider utility company financing, as did the Thermo Electron study.

The major difference between the RPA and the Thermo Electron projections is the distinction made by RPA between technically "suitable" and "unsuitable" portions of the total steam use. Based on discussions held in the field with more than 50 industrial companies, it was concluded that about $46 \%$ of the steam use in the six industries studied was technically unsuitable for cogeneration.* Reasons for this ranged from the small size of some individual steam requirements to the mismatch between the dynamic fluctuations in steam and electricity demand loads for a given establishment.

To evaluate the economically attractive portion of the technically suitable process steam load, RPA developed estimates of the return-oninvestment (ROI) required by each industry for investment in cogeneration projects. An accumulative distribution plot of cogeneration investment potential vs ROI was prepared for each industry. The expected ROI was calculated for each type of cogeneration activity for each industry, and the expected economic level of implementation was then obtained from the distribution plots.

A very similar procedure was used in the TE-I study to determine the economic level of cogeneration investment. However, the Thermo Electron group used only une compositc investment probahility distribution curve for the three industries considered. It was based on the industry-wide average after-tax rates of ROI and was subjectively scaled to show the effect of higher and lower rates of return. In contrast, the RPA study developed separate investment vs ROI distribution curves for each of six industries and established the functional relationships from extensive discussions with investment decision makers in each industry. However, when we compared the distribution curves from both

"The RPA group did not study process steam use outside the six industries of interest; however, they estimate that only $5 \%$ of such steam is technically suitable for cogeneration. 
studies, the single Thermo Electron distribution was found to lie quite close to the centerline of the six RPA distributions.

The RPA study does not have a separate projection for each mode of cogeneration, and only two cases are developed: (1) the "low electricity" case for steam turbine topping only and (2) the "high electricity" case for a mix of $75 \%$ steam turbine, $15 \%$ gas turbine, and $10 \%$ diesel engine modes. The "high electricity" case is estimated to represent the maximum extent to which the gas turbine and diesel engine modes could be utilized by 1985 .

As shown in Table 1 , the RPA analysis projects a minimum energy saving in 1985 of 0.5 quads and a maximum saving (with strong government programs) of 0.9 quads* for the six industries studied. This is a lower level of energy saving than is projected by the other studies reviewed. This smaller energy saving is primarily a consequence of the small industrial process steam load considered suitable for cogeneration. in the RPA study. Also, RPA estimates that only $25 \%$ of the process steam demand will be served by the gas turbine and diesel engine modes of cogeneration (which further restricts the potential for energy conservation).

In the RPA analysis, the use of industrial steam is projected to increase at 4.1\%/year from 1976 on, giving a "technically suitable" steam base of 3.5 quadst in 1985. Without government programo to stimulate cogeneration, half of this steam would be obtained from new and presently existing industrial cogeneration systems, With maximal government programs, three-fourths of the technical potential would be utilized. These levels of implementation would produce from 10 to $23 \mathrm{GW}$ of electricity (see lable 4), depending on the mode of cogeneration employed.

The RPA estimates for 1985 levels of cogenerated electricity are significantly lower than the Thermo Electron estimates not only because

\footnotetext{
* The RPA study actually presents only the estimated energy savings from "additional" cogeneration by 1985. We have added 0.16 quad of energy savings attributable to presently existing industrial cogeneration.

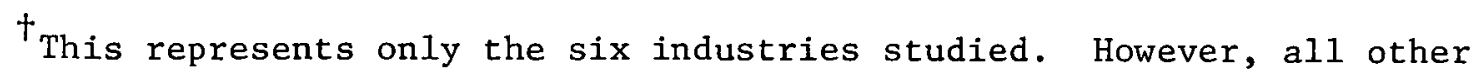
industry is estimated to have only a total of 0.4 quad of steam demand technically suitable for cogeneration.
} 
of the lower industrial steam base considered suitable for cogeneration, but also because of the limited expectations for gas turbine and diesel engine applications.

\subsection{The CONAES Industry Resource Group (IRG) Study ${ }^{4}$}

This study is still unpublished and has been included in our discussion because of this author's participation in the CONAES work.

As part of a larger program studying major energy alternatives for the U.S., a group of industrial energy specialists was assembled to evaluate the potential for industrial energy conservation activity. ${ }^{\dagger}$ Industrial cogeneration was one of the conservation activities examined. Using the basic data developed in the Dow study and the TE-I study, an evaluation was made of the effect of operational and institutional constraints on the expected level of industrial cogeneration. This included consideration of factors such as operational load balancing for steam and electricity use in industrial plants, economic cost of standby facilities to backup cogeneration operations, willingness of industrial managers to commit to firm contracts for surplus electricity sales, and the expected ratio of private sale price for surplus industrial electricity to the purchase price of displaced electricity. Much of this evaluation was necessarily subjective.

The IRG study concluded that expected implementation of cogeneration would be about 30 to $40 \%$ of the maximum technological potential. The IRG study evaluated several alternative "scenarios" for future energy prices and economic growth. Within these scenarios, the expected annual fuel saving from cogeneration by the year 2010 would be 2 to 4 quads (Table $1)$. This represents a by-product electricity generation of 45,000 to $90,000 \mathrm{MW}$ (Table 4). When interpolated back to 1985 , this is a lower

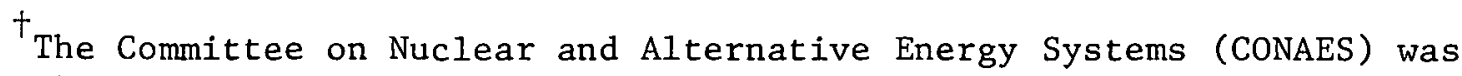
set up by the National Research Council to evaluate the future need for nuclear energy. As part of the study, an Industry Resource Group (IRG) was assembled to identify and evalute industrial energy conservation options. The IRG was composed of representatives from the aluminum, cement, chemical, food, glass, paper, and steel industries. 
estimated level of implementation than shown in any of the other studies reviewed.

\subsection{The Ross and Williams (R\&W) Study $^{5}$}

This study also contains no new independent evaluation of the technical basis for cogeneration and relies upon the data presented in the Dow and the TE-I reports. Ross and Williams estimate that industrial steam production represents $17 \%$ of the total U.S. energy use. This is the same fraction of total energy use previously reported in the SRI sludy, ${ }^{3}$ and 1 appears to be substantially larger than the actual leve 1 of industrial steam use. With the further assumption that cogeneration Irom $50 \%$ of the steam base is feasible and the rngeneration saves half the fuel otherwise required for electricity generation, the R\&W study estimates a potential fuel saving of 2.6 quads (Table 1 ).

If we use the R\&W estimate that cogeneration saves half the fuel input normally required for electricity generation and a value of $10,000 \mathrm{Btu} / \mathrm{kWhr}$ for the normal fuel requirement, we find that R\&W projects approximately 59,000 MW of by-product electricity from cogeneration. This indicates an alpha value of about 0.3 and suggests that the estimate is based on steam turbine cogeneration or a combination of steam turbine and gas turhine modes :

The R\&W study aleo prcsents cstimates for fuel savings from tocal energy systems (MIUS) cogeneration. The study estimates a feasible potential of half of all multifamily housing units to be equipped with cotal energy systems for a fuel saving of 0.31 quad. Additionally, it is estimated that half of all commercial building units could be so equipped for a fuel saving of 0.64 quad. No data are presented showing the absolute magnitudes of heat and electricity generation resulting from these cogeneration applications, nor is the basic source for the estimate given.

\subsection{The Brookhaven Studies ${ }^{7}, 8$}

The Brookhaven reports discuss the potential for central utility station cogeneration to supply by-product heat for district heating. The 
cost of district heating systems is evaluated for several U.S. cities. The potential for district heating is assumed to be that portion of the U.S. residential and commercial heating demand which can be served at a cost that is less than the cost of heat derived from imported petroleum in one case ${ }^{7}$ and from utility electricity in the other. ${ }^{8}$ It is estimated on these bases that 61 million and 103 million people, respectively, would find district heating to be economically attractive. This represents a total present heat demand of 2.1 quads in the first case and 3.6 quads in the second. The second study also presents projections showing the economically attractive potential for district heating growing to 4.2 quads in 1985 and 5.1 quads in the year 2000 (Table 4).

Assuming that these district heating loads are met with by-product heat from utility central station power plants, the first study projects a total U.S. fuel savings of $\sim 3.3$ to 3.8 quads/year (Table 1 ). This projection represents the primary fuel that otherwise would have been required for space and water heating, minus the additional fuel required by the utility to maintain constant electricity production.

The second Brookhaven study projects fuel savings (Table 1) of 4.7 (1972), 5.2 (1985), and 5.0 (2000) quads while serving district heating loads of $3.6,4.2$, and 5.1 quads, respectively. Again, these are net savings with the increased fuel used by the utilities deducted from the fuel saved by the consumers. This study assumes that the average thermal efficiency for conventional home heating systems will increase from about $58 \%$ in 1972 to $74 \%$ in 2000 .

The energy conservation potential for district heating as reported in these Brookhaven studies may be overestimated. This writer is aware of recent unpublished work at Oak Ridge and Argonne National Laboratories which indicates that the retrofit (or new system) costs to a utility for the production and distribution of district heat may be higher than estimated in the Brookhaven work. At the higher cost the potential market (and cncrgy eavings) wolld be about half the size reported by Brookhaven.

\subsection{The ORNL/HUD Study ${ }^{9}$}

To our knowledge, this study is the only one containing a national projection of potential for the MIUS form of cogeneration that has been 
developed from basic data. The study indicates that MIUS installations are economically competitive with conventional heating and electricity supply systems for large miltifamily housing developments.(i.e., 200 or more dwelling units per project). The authors estimate that 28 to $50 \%$ of multifamily housing built after the year 1980 would represent a feasible market for MIUS installation. If retrofit installations are considered, the total annual market could be from 400,000 to 750,000 dwelling units per year. By the year 2000, 8,000,000 to $15,000,000$ dwelling units could be using MIUS at a primary fuel saving of $225 \%$ per unit. At the projected usage levels for conventional heat and electricity in the absence of MIUS, this represents an annual saving of 0.3 to 0.6 quad (Table 1 ).

\subsection{Secondary Studies}

In the last one to two years, several investigators have published estimates of the potential energy savings from cogeneration according to their interpretation of the original work discussed previously. Each of these estimates will be reviewed briefly.

In two published reports, ${ }^{0,11}$ Amory Lovins makes three statements respecting the energy saving potential of cogeneration:

Cogeneration and more efficient use of electricity could together reduce our use of electricity by a third and our central station generation by 60 percent. (p. 74, Ref. 10)

Utility owned industrial cogeneration by 1985 could be profitably generating $26-42 \%$ more than all IJ.S. utility sales of electricity in 1975. (p. 26, Ref. 11)

It appears that cogeneration in 2000 could provide electricity conservatively equivalent to over two-thirds of the total 1975 electrical demand, directly displacing over $200 \mathrm{GW}(\mathrm{e})$ of projected nuclear capacity. (p. 33, Ref. 11)

In the first quotation, since cogeneration and unspecified other electricity conservation measures are lumped together, it is not possible to identify the estimated potential savings for cogeneration alone. As a basis for this statement, Lovins cites the work of Ross and Williams ${ }^{5}$ that was discussed previously. 
The second and third quotes above are somewhat inconsistent and may have been reconciled in the final paper, which has not yet been published. As the basis for the first of these two statements, Lovins cites the study by Thermo Electron ${ }^{2}$ that was discussed previously (TE-I). The Thermo Electron study does not show a case projecting this high level of implementation. The maximum economic level (with federal tax incentives) projected for cogeneration in three industries equals $79 \%$ of 1975 utility electricity generation. If these three industries (chemicals, petroleum refining, and paper) are assumed to represent about $55 \%$ of total industrial steam use, one could estimate an overall level in the range shown by Lovins as "profitable." However, the difference between the economic maximum potential and the truly "profitable" level can be very substantial and is dependent upon many assumptions with respect to federal financing incentives, electricity pricing alternatives, and the removal of institutional constraints.

The last statement quoted above from Lovins was based on a report by Von Hippel and Williams, ${ }^{12}$ which is discussed below. The ultimate source for this estimate was also the Thermo Electron (TE-I) report and is subject to the considerations just discussed.

The Von Hippel and Williams report includes an analysis of the effect that implementation of cogeneration might have on the growth of nuclear power. This report projects a level of electricity generation from cogeneration in the year 2000 equivalent to $230 \mathrm{GW}$ of central station power. The report uses the ERDA-48 projection $^{16}$ for industrial process heat (18 quads), couplled with a fraction for steam (0.75) from the SRI study $^{13}$ to obtain an estimate for industrial steam use in the year 2000 . Although this quantity is not explicitly stated, by following their assumptions we calculate it to be about 13.5 quads. From our earlier discussion of future industrial steam use, this projection appears to be conservatively low.

Von Hippel and Williams deduct from this steam demand a portion assumed to be derived from solar energy (2.1 quads per ERDA-48) and further assume that only $60 \%$ of the remaining steam could be economically obtained from cogeneration. It is also assumed that all this steam will be produced from the gas turbine mode of cogeneration (alpha $=0.7$ ). With a 
final assumption that central station power plants operate at a capacity factor of about $70 \%$, the annual electricity generation from cogeneration is estimated to equal $230 \mathrm{GW}$ of central station generation capacity.

It should be noted that all the studies projecting the higher levels (i.e., above 100,000 MW) of economically attractive electricity production from cogeneration assume that the gas turbine mode will be employed and that the problem of obtaining a clean burning fuel to replace gas and distillate oil will be solved. Also, there is a general assumption that all operational, attitudinal, regulatory, and other institutional problems associated with cogeneration will be solved completely so that the economic maximum level of cogeneration will be installed. 


\section{CONCLUSIONS}

Cogeneration of electricity and useful heat probably represents the largest single opportunity for energy conservation in the United States. However, like most opportunities, it may be so fraught with problems that to many observers it appears largely unachievable. Thus, we find that the energy-savings potential projected for cogeneration is largely dependent on the optimism of the forecaster with respect to the tractability of the problems involved. Some, like Lovins, ${ }^{10,11}$ indicate a potential annual savings as high as 13 quads ( $10^{15} \mathrm{Btu}$ ) by the year 2000. Others, such as Resource Planning Associates (RPA), ${ }^{6}$ expect about 1 quad* by 1985 and (by inference) only a modest increase by 2000 . The difference between these two estimates appears to be more closely related to the extent to which each forecaster has examined the problems involved than to differences in basic data.

Lovins' projections are based on full utilization of the industrial steam base for cogeneration, employing almost exclusively a technology (combustion turbines) that produces a high electricity yield. However, his estimate does not represent an original investigation but is derived from the studies of other analysts.

Conversely, during the RPA study, researchers had many discussions with, and obtained basic data from, a substantial number of industrial people who are or would be involved in the cogeneration activity. As a result, the RPA researchers expect only a portion of the industrial steam base to be "suitable" for cogeneration; they also expect the bulk of the implementation to use the conventional steam turbine technology, which yields. less cogenerated electricity.

Other projections of potential energy savings from industrial cogeneration range between the extremes quoted above and vary in their assumptions concerning the appropriate steam base and the technology to be employed. All studies agree that the maximum potential (whatever it may be) will be attained only with governmental programs that increase the

\footnotetext{
${ }^{*}$ In addition to presently existing cogeneration savings (about 0.6 quad).
} 
incentive for cogeneration and solve the problems associated with the economic use of surplus electricity from industrial cogeneration plants. Other forms of cogeneration (such as district heating and total energy systems) also have significant energy-savings potential but have major implementation problems. If these can be fully resolved, another 5 or more quads of energy saving could be obtained.

In total, it appears that cogeneration, in its various forms could, under ideal conditions, reduce our national energy consumption by almost $10 \%$. In practice, however, actual energy savings are likely to be much smaller, depending largely on the extent to which the implementation problems are solved. 


\section{REFERENCES}

1. R. S. Spencer et a1., Energy Industrial Center Study, prepared for the National Science Foundation by The Dow Chemical Company, Midland, Mich., June 1975.

2. S. E. Nydick et al., A Study of In-plant Electric Power Generation in the Chemical, Petroleum Refining and Paper and Pulp Industries, prepared for the Federal Energy Administration by the Thermo Electron Corporation, Waltham, Mass., July 1976.

3. G. M. Hatsopoulos et al., A National Policy for Industrial Energy Conservation, published by the Thermo Electron Corporation, Waltham, Mass., Apri1 1977.

4. R. W. Barnes et al., Industry Resource Group Report to the Committee on Nuclear and Altemate Energy System, study sponsored by the National Research Council 1976-77 (unpublished as of August 1977).

5. M. H. Ross and R. H. Williams, "The Potential for Fuel Conservation," Technology Review, February 1977.

6. P. G. Bos et al., The Potential for Cogeneration Development in Six Major Industries by 1985, prepared for the Federal Energy Administration by Resource Planning Associates, Cambridge, Mass., September 1977.

7. J. Karkheck, E. Beardsworth, and J. Powe11, Technical and Economic Aspects of U.S. District Heating Systems, prepared for the Energy Research and Development Administration by Brookhaven National Laboratory, Upton, N.Y., April 1976.

8. J. Karkheck, J. Powe11, and E. Beardsworth, "Prospects for District Heating in the United States," Science, 195, 11 (March 1977).

9. W. R. Mixon et al., Technology Assessment of Modular Integrated Utility Systems, prepared for the Department of Housing and Urban Development by Oak Ridge National Laboratory, Oak Ridge, Tenn., December 1976.

10. A. B. Lovins, "Energy Strategy: The Road Not Taken?," Foreign Affairs, October 1976 .

11. A. B. Lovins, "Scale, Centralization and Electrification in Energy Systems," address prepared for the Symposium on Future Strategies for Energy Development, sponsored by Oak Ridge Associated Universities, Oak Ridge, Tenn., October 1976. (Discussion draft - subject to revision).

12. F. Von Hippel and R. H. Williams, "The Potential for Nuclear Power Growth." Center for Environmental Studies, Princeton University, July 1976 (draft copy). 
13. Patterns of Energy Consumption in the United States, prepared for the Office of Science and Technology by Stanford Research Institute, Menlo Park, Calif., January 1972.

14. J. C. Wilcox, Jr., "Fuel Conservation in Industrial Boilers," testimony before the Senate Commerce Committee, June 10, 1974.

15. R. W. Barnes and G. L. Decker, An Evaluation of Alternate Energy Sources for Process Heat, prepared for the National Science Foundation by The Dow Chemical Company, Midland, Mich., September 1975.

16. A National Plan for Energy Research, Development and Demonstration, ERDA-48, published by the Energy Research and Development Adminstration, Washington, D.C., June 1975. 
Appendix

ANALYSIS OF INDUSTRIAL POWER/STEAM RATIOS

It is expected that the real (deflated) price of electricity sold to industry by electrical utilities will continue to increase. As this occurs, it will become increasingly attractive for industrial plants to produce their own electricity using cogeneration systems. However, since all industrial plants do not use steam and electricity in fixed proportions, there is a question about how effectively the total steam base can be used. Some plants could produce far more electricity than they use and would need to sell the surplus at a satisfactory price to justify the additional cogeneration. Others might consume more electricity than they could produce using their total steam base and thus still need to purchase some electricity.

The data needed to answer the above question are almost unavailable; however, a study* sponsored by Oak Ridge National Laboratory furnishes some pertinent data. This study presents steam and electricity consumption for almost 300 large U.S. industrial plants in the major process industries. Table A.1 shows the following distribution of steam and electricity use by individual industrial plants obtained from an analysis of the data from this study. From Table A.1, it appears that $80 \%$ of the plants have an electricity to steam use ratio ("alpha") of less than 0.25 .

The implication of this analysis is that for the majority of U.S. industrial plants (if the sample analyzed is representative), electrical energy use is small with respect to steam energy use. If these plants were to install cogeneration only to satisfy their own steam and electricity needs, they would likely install steam turbine topping systems with alpha values in the range 0.1 to 0.25 . Choice of another mode of cogeneration such as a gas turbine or a diesel engine, both of which normally have alpha values above 0.5 , would depend upon having an attractive market for sale of the surplus electricity, which in many cases would be five or ten times larger than the internal use.

\footnotetext{
*The Potential Industrial Market for Process Heat from Nuclear Reactors, ORNL/TM-5516 (July 1976), prepared for Oak Ridge National Laboratory by Dow Chemical Company, Midland, Mich.
} 
Table A.1. Distribution of steam and electricity

\begin{tabular}{|c|c|c|c|}
\hline $\begin{array}{l}\text { Electricity/steam } \\
\text { ratio } a\end{array}$ & $\begin{array}{l}\text { Number of } \\
\text { plants }\end{array}$ & $\begin{array}{c}\text { Total } \\
\text { steam use } \\
\left(10^{6} \mathrm{lb} / \mathrm{hr}\right)\end{array}$ & $\begin{array}{l}\text { Percent } \\
\text { of } \\
\text { steam use }\end{array}$ \\
\hline$<0.05$ & 35 & 40.3 & 13.8 \\
\hline $0.05-0.1$ & 67 & 68.0 & 23.3 \\
\hline $0.11-0.15$ & 85 & 90.9 & 31.2 \\
\hline $0.16-0.2$ & 30 & 31.2 & 10.7 \\
\hline $0.21-0.25$ & 8 & 8.6 & 3.0 \\
\hline $0.26-0.3$ & 10 & 9.3 & 3.2 \\
\hline $0.31-0.35$ & 12 & 11.0 & 3.8 \\
\hline$>0.33$ & 35 & 32.2 & 11.0 \\
\hline Total & 282 & 291.5 & 100.0 \\
\hline
\end{tabular}


ORNL/TM-6602

\section{Internal Distribution}

1. T. D. Anderson

2. M. Baker

3-12. R. W. Barnes

13. R. S. Carlsmith

14. T. E. Cole

15. H. Falkenberry

16. L. C. Fuller

17. J. F. Harvey

18. J. E. Jones

19. M. A. Karnitz

20-29. O. H. Klepper

30. M. Levenson

31. M. L. Myers
32. H. Postma

33. M. W. Rosenthal

34. Dunlap Scott

35. M. R. Sheldon

36. M. J. Skinner

37. I. Spiewak

38. H. E. Tramme11

39. D. B. Trauger

40-41. Central Research Library

42. Document Reference Section

43-45. Laboratory Records Dept.

46. Laboratory Records (RC)

\section{External Distribution}

47. Garet Bornstein, ERA, Vanguard B1dg., Room 548, 111120 th Street, N.W. , DOE, Washington, D.C. 20461

48. R. L. Cowles, Conservation and Solar Applications, DOE, 12th and Pennsylvania Avenue, NW, Washington, D.C. 20461

49. Alton P. Donnel, Power Supply \& Reliability Division, DOE, Room 5112, 825 No. Capitol St., N.E., Washington, D.C. 20426

50. John Facey, Energy Technology, DOE, Mail Stop 4128, 20 Massachusetts Avenue, Washington, D.C. 20545

51. Tom Grahame, DOE, P\&E, Utilities, Mail Stop 4324, Washington, D.C. 20545

52. C. Grua, ECT, DOE, Mail Stop E-201, Washington, D.C. 20545

53. D. G. Harvey, Industrial Energy Conservation Division, DOE, 20 Massachusetts Avenue, Washington, D. C. 20545

54. Eric Lister, Fossil Energy, DOE, Mail Stop 4128, Washington, D.C. 20545

55. R. McFarren, Resource Applications, DOE, Federal Bldg., 12th and Pennsylvania Avenue, NW, Washington, D.C. 20461

56. John Muller, Conservation, DOE, Room 5324, Federal Building, 12th and Pennsylvania Avenue, NW, Washington, D.C. 20461

57. Richard G. Oeh1, Energy Technology, Mail Stop B-107, DOE, Washington, D.C. 20545

58. Bill Rankin, Region V, DOE, 1655 Peachtree Street, N.W., Eighth Floor, Atlanta, Ga. 30309 
59. Michael Resner, Energy Technology, DOE, Mail Stop 404, 600 St., Washington, D.C. 20545

60. William Rice, RA, DOE, Washington, D.C. 20545

61. Alan M. Rubin, Advanced Systems and Materials Production Division, Mail Stop B-107, DOE, Washington, D.C. 20545

62. Norton Savage, Power Supply \& Reliability Reporting Branch, DOE, Room 5112, 825 No. Capitol St., N.E., Washington, D.C. 20426

63. William F. Savage, Advanced Systems and Materials Production Division, Mail Stop B-107, DOE, Washington, D.C. 20545

64. Alan Starr, ERA, Vanguard Bldg., Room 538, 1111 20th Street, N.W., DOE, Washington, D.C. 20461

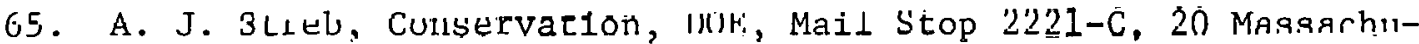
setts Avenue, Washington, D.C. 20545

66. C. J. Swet, ET/STOR, DOE, Mail Stop 426, fOn F., St., Washington, D.C. 20545

67. J. G. Vlahakis, Fossil Energy, DOE, 20 Massachusetts Avenue, Mail Stop 4128, Washington, D.C. 20545

68. F. E. Dearing, Nuclear Research and Development Division, DOE, Oak Ridge, Tenn. 37830

69. Ismael Almodovar, Center for Energy and Environment Research, University of Puerto Rico, Caparra Heights Station, San Juan, Puerto Rico 00935

70. Symour Alpert, Electric Power Research Institute, 3412 H1llview Ave., Palo Alto, Calif. 94304

71. William .J. Amos, Energy Systems Dept., Cryogenic Systems D1v., Air Products and Chemicals, Inc., P.0. Box 538, Allentown, Pa. 18105

72. Joseph M. Anderson, Dir., Division Development, Chemical Division, PPG Industries, Inc., 1 Gateway Center, Pittsburgh, Pa. 15222

73. Michael Barnes, KVB, Inc., $600 \mathrm{~S}$. County Road, No. 18, Minneapolis, Minn. 55401

74. Theodore Beresovski, ERDA Scientific Representative, Science Office, American Embassy, 2, Avenue Gabriel, 75382 Paris, France

75. Melvin G. Berger, Public Counsel Section, Antitrust Division, Department of Justice, Ronm 6315, Star Bldg., 10th and Constitution Streets, N.W., Washington, D.C. 20530

76. D. J. Blickwede, Bethlehem Steel Corp., Bethlehem, Pa. 18016

77. James D. Borden, Energy and Materials Dept., E. I. duPont de Nemoure \& Co., Wilmington, Del. 19898

78. Peter G. Bos, Resource Planning Assoc., Inc., 44 Brattle St., Cambridge, Mass. 02138 
79. Shelby Brewer, Mail Stop B-107, Office Nuclear Energy Programs, DOE, Washington, D.C. 20545

80. Donald A. Burge, The B. F. Goodrich Co., Akron, Ohio 44318

81. W. Burton, Energy Resources, TVA, 1200 Commerce Union Bank B1dg., Chat tanooga, Tenn.

82. Tommy D. Buchanan, ERA/US, Vanguard Building, Room 538, 1111 20th Street, N.W., Washington, D.C. 20545

83. Harry A. Campbell, Facilities and Planning, Vulcan Material Company, P.0. Box 12283, Wichita, Kan. 67277

84. J. A. Casazza, Stone \& Webster Management Consultants, 90 Broad Street, New York, N.Y. 10004

85. Thomas R. Casberg, Office of Construction Standards \& Design (MRA\&L), Department of Defense, Room 3C, 764 Pentagon, Washington, D.C. 20301

86. James Carter, Minnesota Energy Agency, 740 American Center Bldg., 160 E. Kellogg Blvd., St. Paul, Minn. 55101

87. Steve Cavros, CS-313, Mail Stop 2221-C, 20 Massachusetts Avenue, N.W., Washington, D.C. 20545

88. D. E. Cochran, Duval Corporation, 4715 East Fort Lowell Road, Tucson, Ariz. 85712

89. Jacqueline Cook, FEA Audit Site, Government Accounting Office, Room 222, OPOB, 1100 Pennsylvania Avenue, N.W., Washington, D.C. 20461

90. E. N. Cramer, Southern California Edison Company, Box 800, Room 453, Rosemead, Calif. 91770

91. J. H. Crowley, United Engineers and Constructors, Inc., 1401 Arch St., Philadelphia, Pa. 19105

92. John Davidson, Council on Environmental Quality, Room 5027, 722 Jackson Place, N.W., Washington, D.C. 20006

93. G. L. Decker, Kalser Aluminum \& Chemfcal Corp., 300 Lakes1de Dr., Oakland, Calif. 94643

94. G. F. Diddle, Associated Electric Cooperative, Inc., P.0. Box 754, Springfield, Mo. 65801

95. Peter Donnelly, Argonne National Laboratory, 9700 South Cass Avenue, Argonne, I11. 60459

96. Dennis Drapkin, Office of Tax Legislative Counsel, Department of Treasury, Room 4441, Main Treasury, 15th \& Pennsylvania Ave., N.W., Washington, D.C. 20220

97. George Englesson, United Engineers and Constructors, 30 South, 17th Street, Fourth Floor, Philadelphia, Pa. 19101

98. R. L. Forrester, Sr., Stone \& Webster Engineering Co., Cherry Hill Operations Center, 3 Executive Campus, P.0. Box 5200, Cherry Hill, N.J. 08034 
99. Andrew Foster, C. T. Main, Southeast Tower, Prudential Center, Boston, Mass. 02199

100. Jack Goodell, Bechtel Power Div., 1233 West Loop South, Houston, Tex. 77027

101. Charles Glass, Gulf States Utilities Co., 283 Liberty Ave., Beaumont, Tex.

102. M. W. Golay, Dept. of Nuclear Engineering, Massachusetts Institute of Technology, 138 Albany St., Cambridge, Mass. 02139

103. Jackson Gouraud, 73054 Forrestal, 1000 Independence Avenue, S.W., Washington, D.C. 20545

104. Allen Greene, Cities Services, P.O. Box 300, Tulsa, Okla. 74100

105. Dan Greeno, Energy Management, Stauffer Chemical Co., Westport, Conn. 05880

106. Joseph F. Gustaferro, office of the Secretary, Department of Commerce, Room 1604, Washington, D.C. 20230

107. H. L. Harkins, Power Systems Engineering, Inc., P.0. Box 19398, Houston, Tex. 77024

108. William F. Heavey, Jr., Office of Regulatory Analysis, Federal Energy Regulatory Commission, 825 North Capitol Street, N.E., Washington, D.C. 20426

109. T. C. Hoyt, EBASCO, Two Reactor Street, New York, N.Y. 10006

110. Ken Israel, Division of Corporate Regulations, Securities and Exchange Com., 500 North Capilul Street, Roum 2329, Washingtur, D.C. 20549

111. H. R. Irvine, Feedstock/Fuels Division, Exxon Chemical Co., USA, 1333 West Lüp South, Houston, Tex. 77027

112. Herb Jaehne, Northern States Power, 414 Nicollett Mal1, Minneapolis, Minn. 55401

113. Roger L. Johnson, Policy and Evaluation, Mail Stop 7117, 20 Massachusetts Avenue, Washington, D.C. 20545

114. A. E. Kakretz, Advanced Energy Systems, B1dg. 2, Rm. 551, General Electric Company, 1 River Road, Schenectady, N.Y. 12345

115. J. Karkheck, Brookhaven National Laboratory, Upton, L.I., N.Y. 11973

116. Dan Kluckhuhn, Department of Housing and Urban Development, 451 7 th Street, S.W., Room 8158, Washington, D.C. 20410

117. Gordon J. Leaman, Jr., CoNOCO Coal Development Co., High Ridge Park, P.0. Box 1050, Stamford, Conn. 06904

118. C. C. Lee, Environmental Protection Agency, 5555 Ridge Avenue, Cincinnati, Ohio 45268

119. Roger W. A. LeGassie, Planning, Analysis, and Evaluation, Energy Research and Develupment Administration, Washington, D.C. 20545 
120. James Liles, Office of Regulatory Analysis, Federal Energy Regulatory Commission, Room 9207, 825 North Capitol Street, N.E., Washington, D.C. 20426

121. Quentin Looney, Electric Power Research Institute, 3412 Hillview Avenue, P.0. Box 10412, Palo Alto, Calif. 94304

122. H. G. MacPherson, Institute for Energy Analysis, Oak Ridge Associated Universities, P.0. Box 117, Oak Ridge, Tenn. 37830

123. A. Michael Maher, Office of Energy Programs, Department of Commerce, Room 3011, 14th \& E. Streets, N.W., Washington, D.C. 20230

124. P. L. Maisto, BASF Wyandotte Corporation, 100 Cherry Hil1 Road, P.0. Box 181, Parsippany, N.J. 07054

125. Peter Margen, AB Atomenergi, Fack, S-61101 NYKOPING 1, Sweden

126. W. J. McCarthy, Jr., Vice President, The Detroit Edison Company, 1450 Pilgrim Road, Birmingham, Mich. 48009

127. A. T. McMain, General Atomic Co., P.0. Box 81608, San Diego, Calif. 92138

128. C. L. McDonald, Battelle Pacific Northwest Laboratory, P.O. Box 999, Richland, Wash. 99352

129. N. F. McLead, Chemical Division, Uniroyal Chemical Division of Uniroyal, Inc., Naugatuck, Conn. 06770

130. Richard F. Messing, A. D. Little, Inc., Acorn Park, Cambridge, Mass. 02140

131. Charles Meyer, GE Tempo, 816 State Street, P.o. Drawer QQ, Santa Barbara, Calif. 93102

132. Dick Meyer, The Firestone Tire and Rubber Company, 1200 Firestone Parkway, Akron, Ohio 44317

133. Max Novinsky, Office of Facilities Engineering, Department of Health, Education and Welfare, Washington, D.C. 20201

134. S. E. Nydick, Thermo Electron Corporation, 101 lst Avenue, Walthall, Mass. 02156

135. Marian Obis, Department of Treasury, Room 921, Washington Building, Washington, D.C. 20220

136. I. Oliker, Burns and Roe, 496 Kinderkamach Road, Orade11, N.J. 07649

137. Mary Oliver, Securities and Exchange Comm., Room 2319, 500 North Capitn1 Street, Washington; D.C. 20549

138. G. W. Oprea, Jr., Houston Lighting and Power Co., P.0. Box 1700, Houston, Tex. 77001

139. Clinton W. Phillips, Integrated Energy Systems, National Bureau of Standards, Room A-146, Building 225, Washington, D.C. 20234

140. Richard B. Pool, Kaiser Aluminum \& Chemical Corp., 300 Lakeside Dr., Oakland, Calif. 94643 
141. Lew Pugliaresi, Office of Policy Planning, Environmental Protection Agency, Room 3006, 401 M. Street, S.W., Washington, D.C. 20460

142. James Ragland, Shell Oil Company, P.0. Box 2463, Houston, Tex. 77001

143. J. L. Renzetti, Naval Nuclear Power Unit, 13101 Pelfrey Lv., Fairfax, Va. 22030

144. Charles F. Reusch, Office of General Counsel, Federal Energy Regulatory Commission, 825 North Capitol Street, N.E., Washington, D.C. 20426

145. Jerome H. Rothernberg, Department of Housing and Urban Development, 451 7th Street, S.W., Room 8158, Washington, D.C. 20410

146. John Schaefgen, Nation $\perp$ Bureau of standards, Koom Al46, Building 225, Washington, D.C. 20234

147. Kenneth F. Seplow, Kidder, Peabody \& Co., 10 Hanover Square, New York, N.Y. 10005

148. David Shaver, Policy Planning Division, Environmental Protection Agency PM-221, 401 M. Street, S.W., Washington, D.C. 20460

149. W. R. Smith, Babcock and Wilcox, P.0. Box 1260, Lynchburg, Va. 24505

150. Warren Soderberg, University of Minnesota, Minneapolis, Minn. 55455

151. W. E. Steger, Treasury Department, Washington Building, Room 921, Washington, D.C. 20220

152. Ron Sundberg, Minnesota Energy Agency, 160 E. Kellogg Boulevard, St. Paul, Minn. 55101

153. Robert A. Walker, Plant Manager, Gulf Oil Chemicals Company, Orange, Tex. 77630

154. Mardy Waits, Borden Chemical Company, 180 East Braud St., Columbus, Ohio 432.15

155. William I. Wheelock, Office of Electric Power Regulation, FERC, 825 North Capitol Street, N.E., Washington, D.C. 20426

156. Malco1m Williams, Gulf States Utilities, 283 Liberty Ave., P.o. Rnx 2951, Realymont, Tex. 77704

157-183. Technical Information Center, DOE, Oak Ridge, TN 37830

184. Assistant Manager, Energy Research and Development, DOE-ORO 